\title{
SHAKESPEARE E O DIREITO
}

RESUMO: Este trabalho pretende, a partir de O Mercador de Veneza de Shakespeare, mostrar que uma nova maneira de se pensar o direito e a justiça deve levar em conta a imaginação literária, sublinhando, justamente, a cumplicidade que há entre o direito, a filosofia e a literatura. A filosofia e a teoria do direito devem não só pressupor, mas estarem comprometidas com as tramas que estão na base das suas problematizações. Shylock não perdoa o intrépido, embora melancólico mercador e reivindica o seu direito (seu contrato). Que direito? O que é o direito? Shylock e Antonio, judeu e cristão, agiota e mercador, ambos demandam justiça. Que justiça? E o que é a justiça? Como se pode observar, a prosa filosófica tradicional não é a única linguagem para as intrincadas questões que são enfrentadas na esfera da filosofia e da teoria do direito. Tais questões podem surgir da emoção e da complexidade dos versos (e da prosa) shakespearianos.

\section{SHAKESPEARE AND THE LAW**}

Shylock. ... The pound of flesh which I demand of him

Is dearly bought, is mine, and I will have it. If you deny me, fie upon your law!

There is no force in the decrees of Venice.

* Doutora em Filosofia - New School for Social Research, Prof. ${ }^{a}$ Assistente de Teoria do Estado e Direito Constitucional, Departamento de Direito Público, Faculdade de Direito, UFPR.

** Este trabalho foi originalmente escrito para o seminário Justice, Perjury and Forgiveness com o professor Jacques Derrida no semestre de outono de 1999 na GF da New School for Social Research,
I stand for judgment. Answer; shall I have it? (Act IV, scene i)

Shylock. My deeds upon my head! I crave the law,

The penalty and forfeit of my bond. (Act IV, scene i)

Shakespeare (The Merchant of Venice)

NY. Posteriormente, foi apresentado na conferência de primavera da New York College English Association, em abril de 2001, na St. John's University, Queens, NY, com o título The Merchant of Venice: (de)constructing Shakespeare or talking about philosophy, law, literature and justice. 


\section{INTRODUCTION}

"My deeds upon my head! I crave the law," says Shylock to the "judge" (Portia) in a Venetian Court of Justice, referring to the penalty and forfeit of his bond, that is, a pound of flesh to be cut and taken from Antonio, the merchant (of Venice). Shylock is a man who speaks, (and through his speech he forwards the plot): "if you deny me, fie upon your law! There is no force in the decrees of Venice!"

Martha Nussbaum, at the very beginning of her book Love's Knowledge, writes that: "there may be some views of the world and how one should live in it - views, especially, that emphasize the world's surprising variety, its complexity and mysteriousness, its flawed and imperfect beauty - that cannot be fully and adequately stated in the language of conventional philosophical prose, a style remarkably flat and lacking in wonder - but only in a language and in forms themselves more complex, more allusive, more attentive to particulars." Indeed, I could not start this paper otherwise but with Shakespeare's verses (and Shylock's claim): "My deeds upon my head! I crave the law!" Shylock states the subject matter of this work: we are bound by this complicity between philosophy and literature, ${ }^{2}$ and, more

1 NUSSBAUM, M. Love's Knowledge. New York and Oxford: Oxford University Press, 1990. p.3.

2 Bloom has a different understanding with which I do not agree. According to him, literary study does not depend upon philosophy and he defends the autonomy of aesthetic in order to stress the "autonomy of imaginative literature and the sovereignty of the solitary soul, the reader not as a person in society but as the deep self, our ultimate inwardness." BLOOM, H. The Western Canon. New York: Harcourt Brace \& Company, 1994. p.10-11. specifically, between philosophy, law and literature. Paradoxically (and unfortunately), my discussion here is mostly in flat, conventional philosophical prose; nevertheless, it aims at showing that a new 'way' for (re)thinking law and justice (in the realm of legal philosophy) has to take into account the literary. imagination by stressing the complicity between law and literature. Legal philosophy and legal theory have not only to presuppose but also to be committed to the crisscrossings and interweavings that are at the very basis of their concerns.

Shylock does not forgive the intrepid yet melancholic merchant and claims the law (his bond). What law? And, what is the law? Shylock and Antonio, Jew and Christian, moneylender and merchant, both demand justice. What justice? And, what is justice? As we can see, the flatness of conventional philosophical prose is not the only language for the intricate issues we face in the realm of jurisprudence. Such issues can also arise from the excitement and complexity of Shakespeare's verse (and prose).

For instance, in The Merchant of Venice verses give the rhythm of love (and the rhythm of hate), "in a 'high' formal poetry which is almost music"; 3 verses judge Antonio (and Shylock). Chats, jokes, and business are in prose. Servants and clowns are prosaic types. As we know, verse and music are based on measures of time. In a certain sense, Shakespeare needs this measurable time in order to say that time is

3 YORK NOTES. The Merchant of Venice. London and Essex: York Press and Longman, 1998, p.51. 
out of joint. ${ }^{4} \mathrm{He}$ thus anticipates a very modern and anguishing dilemma: the need for an irreversible time (which is inscribed in the beat of his verses), the need for consistency to show the inconsistency, the reversals, of time (which are inscribed in the content of his verses). As Derrida nicely puts it: "Voici le coupe de génie, l'insigne trait d'esprit, la signature de la Chose "Shakespeare": autoriser chacune traductions, les rendres possibles et intelligibles sans jamais s'y rédruire."

Therefore, it is necessary to (re)assure what is, on the one hand, the obvious subject matter of this paper: we are impelled by this complicity between philosophy, law, and literature. On the other hand, when we come to the (de)construction of this complicity, either in the conventional prose of legal philosophy or in the dramatic narrative of Shakespeare's The Merchant of Venice, we have already left the realm of the obvious to, perhaps, the most intricate (and challengeable) task. My argument, then, begins here.

I will recount the story of Shakespeare's The Merchant of Venice. To paraphrase Nikulin, ${ }^{6}$ recounting Shakespeare's The Merchant of Venice "may be especially helpful when rigidly established limits

4 "Hamlet. (...) The time is out of joint. (...)" (scene V, act i) See SHAKESPEARE. Hamlet. New York: Signet Classic, 1982.

5 DERRIDA, Spectres de Marx. Paris: Galilée, 1993 , p.47.

6 In a paper entitled Mikhail Bakhtin: A Theory: of Dialogue, Nikulin points out that Bakhtin "is infinitely rich and so may be especially helpful when rigidly established limits between academic disciplines and fields of study are redefined or put into question." NIKULIN, Dimitri. Constellations 5, 1998, p.381. between academic disciplines and fields of study are redefined or put into question." However, the paper is about (n)either Shakespeare (n)or The Merchant of Venice. As Derrida points out, "under the pretext of fiction, literature must be able to say anything; in other words, it is inseparable from the human rights, from the freedom of speech, etc."7

My reading of the play will focus on three aspects: identity, law, and justice. This approach is more or less arbitrary. I believe that legal philosophy has to look beyond the 'fictional and ideal' concept of legal subject inherited from legal positivism in order to (re)think law and justice. Thus, (re)introducing a reflection on who one (we) is (are) in and to legal philosophy is crucial to (re)thinking law and justice themselves. My special interest is in the ambiguities and uncertainties that constitute identity, law, and justice and the deconstructive attitude that makes such reading possible.

\section{SHAKESPEARE'S THE MERCHANT OF VENICE, VERSE, AND PROSE}

\section{Identity}

"I have much ado to know myself," says Antonio to his fellows/friends Salerio and Solanio at the very beginning of The Merchant of Venice. Antonio's very first words are of melancholia: "in sooth I know not why I am so sad." The narrative flows through the rhythm of Antonio's consternation

7 DERRIDA, Jacques. Remarks on deconstruction and pragmatism. In: MOUFFE, Chantal. Pragmatism and deconstruction. New York and London: Routledge, 1996, p.80. 
and sadness, but it is in the end of his speech that we find what bothers him: he has "much ado to know" himself. There we are, with Antonio, facing perhaps the most onerous question one can face: the question of identity. The adjective onerous is not applied by chance here, since we soon realize that the measure of what we are, a pound of flesh "to be cut and taken," will assume the value of three thousand ducats.

Almost all Shakespearean dramas raise the question of identity, which we ask (with the character): 'who am (are) I (we)?' Peter Brook, in a talk in Berlin, said that through Shakespeare's poetry it is possible to "reach into those strange tunnels where all one's experiences are buried waiting to be revived." "While we don't have access to the whole of our lives, Shakespeare's characters dare to have it, and then they inevitably ask: "who am I?" Antonio's first words direct our attention to what is both essential and dramatic: the question of identity and its 'strange tunnels.'

The Merchant of Venice is a drama whose narrative, from its very beginning, ties the characters (and readers) into a troublesome web of literary form and philosophical content. And Shakespearean dramas are like that: a web in which the characters (and we) involve them- (our)selves, somehow weaving their (our) identity. To be dramatic in Shakespeare is to experience the limits of (our) involvement/entanglement in webs/plots. Limits that at the same time define a genre of writing and a literary form - drama - define

8 BROOK, Peter. Evoking Shakespeare. London: Nick Hern Books, 1998, p.14. what one (we) is (are). In Shakespeare, 'being' and 'becoming' are either formally or materially fundamental. With regard to their form, being and becoming are either verbs in the present participle expressing a continuing action or nouns: the 'being' (in plot) or the 'becoming' (entangled) which mean - now moving to their content - the dramatic.

As can be seen, drama is somehow special inasmuch as it demands a performance to arrive at a full interpretation of its meaning. Action and above all conflict are implied in the very idea of drama. It is not by chance that the dramatic is formally expressed by the present participle, which necessarily performs an action: 'being' or 'becoming.' And what can be more dramatic than this experience of being or becoming?

Dramatic situations can evade their conflictual nature no more than their dialogical structure. ${ }^{9}$ When the character asks/reflects about his/her identity, he/she immediately faces a conflict and a dialogue is performed either with the self or with another (different from the self). The dialogue performed with the self when one engenders a reflective attitude; when one's 'I' questions his/her own identity, he/she questions the identity of the other. Nevertheless, even addressing the other, the motivation remains the same: it is "much ado to know myself." Harold Bloom remarks that "Shakespeare from Falstaff on, adds to the function of

9 As Nikulin remarks on Bakhtin about Dostoevsky "Even if communication is possible only through dialogue, and even if this implies the emergence of a certain common ground, this common ground may be extremely antagonistic and conflictual. That is why in Dostoevsky dialogue usually has tragic overtones." See NIKULIN, Constellations, 5, (1998): 393. 
imaginative writing, which was instruction in how to speak to others, the now dominant if more melancholic lesson of poetry: how to speak to ourselves." 10

The enchantment of the Shakespearean drama - the enchantment we find in the encounter of different characters such as Antonio and Shylock - lies in its conflictual structure. This encounter paradoxically and dramatically does not approximate them 'except when it accuses their solitude. Suddenly, we realize that our enchantment, excitement, pleasure (and fear) are the least sensations we experience when we abandon the language of conventional philosophical prose to the language of Shakespeare's drama.

As we can see, the flatness of conventional philosophical prose no longer dominates and translates the issues this paper intends to discuss; rather, they arise from the excitement and complexity of Shakespearean verse (and prose).

The Merchant is a narrative, dramatic in its essence, and this quality of dramatic is the experience of what 'being' or 'becoming' is.

Shylock.... I am a Jew. Hath not a Jew eyes? Hath not a Jew hands, organs, dimensions, senses, affections, passions?-fed with the same food, hurt with the same weapons, subject to the same diseases, healed by the same means, warmed and cooled by the same winter and summer as a Christian is? If you prick us, do we not bleed? If you tickle us, do we not laugh? If you poison us, do we not die? And if you wrong us, shall we not revenge?(...) (Act III, scene i) ${ }^{11}$

${ }^{10}$ BLOOM, Harold. The Western Canon. New York: Harcourt Brace \& Company, 1994, p.49.

11 We can hear in Shylock's speech a claim for what is now understood as the equal protection of the laws.
To be more precise and conceptually attentive, it is the plot that really carries the dramatic in Shakespeare. While a narrative is only a succession of events, a plot is the dramatic arrangement of incidents "in a form having closely reciprocal relations or reflexive reference." 12 However, Shakespeare usually (and engenously) sacrifices (and somehow subverts) the logic of the plot, technically understood as "essentially a spatial constrict, a design of events, with a casual scheme for beginning, middle and end," 13 for psychic crisis. According to Sypher: "the Shakespearian play is often an arena where the theatrical time of plot is at discord with the psychic time we have called duration." 14 The really dramatic measure of a Shakespearean play is the psychic or durative tempo.

Thus, when I claim that the dramatic in Shakespeare is this experience of 'being' (in plot) or 'becoming.' (entangled), I have in mind this plot whose time can be the time of discontinuities or reversals - a time, or rather a tempo, that is dramatic because it cannot be accommodated at the logic of the plot, which is sequential and demands a linear and chronological time. "The psychic drama is lived in discontinuous crises; in contrast to the theatrical sequence of plot the times are always out of joint and tempo instead of time becomes an index of experience." 15

12 SYPHER, The ethic of time. New York: A Continuum Book, 1976, p.8.

\footnotetext{
13 Ibid., p. 44 .

${ }^{14}$ Ibid., p.43-44.

15 Ibid., p. 46.
} 
In The Merchant, the time of the "comedy" can be seen as the temporal sequence towards a happy ending. From a certain point of view, this is what really happens: a happy ending. But to say this is, at least, too simplistic. A time of ambiguities, of uncertainties, is inscribed in The Merchant and experienced either by Antonio or Shylock, for whom the play does not have the conventional happy ending of Elizabethan comedy. The happy ending of Bassanio and Portia, Lorenzo and Jessica, Gratiano and Nerissa, does not arrive for Antonio and Shylock. One can argue that a happy ending is reached in the case of the "stranger, misbeliever, cutthroat dog, kind of devil, unfeeling, harsh" Jew: the loss of his daughter, of his fortune and of his faith in the authority of the law. But, to accept this is to accept the conventional. Nevertheless, what about the ambiguities and uncertainties that do not follow the linearity of the comedic plot? On the one hand, such ambiguities and uncertainties lead us to question the identity of the play as a comedy. But, on the other hand, this does not mean that the 'tragedy' we may identify in the play necessarily implies an unhappy and a miserable end for either the Jew or the merchant. Furthermore, either a happy or an unhappy ending is a conventional demand, a demand of the logic of the plot; we have to turn our attention, rather, to the tragic elements of the play, where a rebellion "against the consistency of character and logic of plot"16 occurs.

So, to say that The Merchant is not a comedy is not simply to accept it as a tragedy.

\footnotetext{
16 Ibid., p.47.
}

It is to stress its subversive time, for instance, the melancholic time that crosses and inscribes itself in Antonio's life as well as in the plot, frustrating a conventional happy ending. Concerning the latter (a happy ending), we suddenly realize that Antonio, despite being the merchant of Venice, is there, in Belmont, a place to which he does not belong, a place that intensifies his estrangement by being the world of possible love. As Heller says; "if one were there in the familiar place and not here in an alien strange world, one would be filled with joy and happiness."17 And as we can see, at the end of the play, despite the verdict of the trial, when Antonio gives voice to his soul in Belmont, we hear the loyal, friendly, yet melancholic merchant:

Antonio. I am th' unhappy subject of these quarrels. (Act V, scene i)

Antonio. I once did lend my body for his wealth, Which but for him that had your husband's ring Had quite miscarried. I dare be bound again, My soul upon the forfeit, that your lord Will never more break faith advisedly. (Act V, scene i)

There is not much enthusiasm in Antonio even when he refers to the return of his ships:

Antonio. Sweet lady, you have given me life and living!

For here I read for certain that my ships

Are safely come to road. (Act V, scene i)

'Life and living' in a world where he is destined to play a part, and that sad one. The defeat of Shylock has been in a way the cause of his

${ }^{17}$ HELLER, Agnes. A Theory of Modernity. Malden, Mass. and Oxford, UK: Blackwell, 1999, p. 194. 
defeat as well, for it has deprived him of the one great gesture of love which would have ended his loneliness and crowned his love with one splendid act. Now he is left with his wealth and his loneliness, surrounded by the lovers and received by Portia at Belmont with words as full of warmth and feeling as those receiving Shylock into the fold of the Church: ${ }^{18}$

Portia. Sir, grieve you not - you are welcome notwithstanding. (Act $\mathrm{V}$, scene i)

Perhaps Antonio still feels the same dramatic disquiet that he expressed to his friends Salerio and Solanio at the beginning of the play. It still bothers him who he is. Not the Christian, nor the wealthy, friendly, and generous merchant of Venice, but he, Antonio, a man that is strange to himself and whose sense of belonging is remote: it is far from Venice or Belmont; it is somewhere that he is not able to reach and recognize as far as he does not know himself.

The ambiguous characters of Antonio and Shylock, the ambiguous identity of the play that moves between comedy and tragedy, show that in a Shakespearean drama nothing is simply there, even when it seems to simply be: "There are more things in heaven and earth, Horatio...," says Hamlet (Act I, scene $v)$. By not being simply there, I refer to what Sypher calls 'illuminations,' that 'is, privileged moments that subvert the plot, giving the very sense of what the dramatic is. The Merchant of Venice is especially dramatic when we can see such illuminations. And when we come to see them (and through them), we realize the irony: for instance,

\footnotetext{
18 MIDGLEY, Graham. The Merchant of Venice: A reconsideration. In: WILDERS (Ed.). Shakespeare: The Merchant of Venice, p.205.
}

that (we) Christians or (we) Jews are damned. This is (our) faith; this is (our) fate. By the way, it is not Antonio nor Shylock but Launcelot, the utterly confused clown, who 'dramatically' states:

Launcelot. (...) for truly, I think you are damned. There is but one hope in it that can do you any good, and that is but a kind of bastard hope neither." (Act III, scene v)

To which Jessica replies:

Jessica: And what kind of hope is that, I pray thee?

And he adds:

Launcelot: Marry, you may partly hope that your father got you not - that you are not the Jew's daughter. (Act III, scene v)

With regard to what, I ask: comedy and/ or tragedy?

\section{THE (AMBIGUOUS) IDENTITY OF THE PLAY: TRAGEDY AND/OR COMEDY}

Solanio. Not love neither? Then let us say you are sad

Because you are not merry; and 'twere as easy For you to laugh and leap, and say you are merry Because you are not sad. Now by two-headed Janus,

Nature hath framed strange fellows in her time: ... (Act I, scene i)

There are tragic signs in Shakespeare's comedies much as there are comic signs in his tragedies. The Merchant is usually understood as a comedy with tragic signs. But a more daring reading could suggest that it is a tragedy with comic signs. In fact, the most interesting thing about the play - and one of its great difficulties - dwells precisely in this ambiguous, Janus-faced identity. Hence, in order to discuss its identity, it is worth taking 
a step back to look at its origins. ${ }^{19}$ And if the origin is the place one or something belongs to or comes from, if it is home, then, in order to know who or what one or something is, it is necessary to take this step back (home).

A brief look at the origin of the story of The Merchant of Venice shows that it is an ancient story found in religious tales from Persia and India. In the western tradition, the Roman Law of the Twelve Tables reinforced tales about a bond of human flesh, prescribing that creditors could, under certain circumstances, divide the body of a debtor among themselves. This story was recounted through folktales and fairytales, which began to take literary form in the twelfth century. The source that is closest to The Merchant is Ser Giovanni Fiorentino's Il Pecorone, a collection of fifty tales published in Italy in 1558 and modeled on the Bocaccio's Decameron. It tells about two Venetian friends, a loan, a lady of Belmonte, a flesh-bond with a Jew, the lady disguised as a lawyer, a trial, a bridal ring, and a marriage at the end. There is also the thirty-second History of the medieval Gesta Romanorum, in which a choice of caskets leads to a marriage whose chooser is a woman. There is also the fourteenth story of Masuccio di Salerno, Il Novellino, dated 1476, in which a daughter runs away to secretly marry a man

19 This brief remark about the origin of the story is based on the following books: SHAKESPEARE, W. The Merchant of Venice. New York: Signet Classic Books, 1997. WILDERS, J. Shakespeare: The Merchant of Venice, London: Macmillan Press, 1999, p.12-13. And also BROWN, J. R. The Merchant of Venice.Cambridge: Harvard University Press, 1959, p.xvii-xxii. YORK NOTES, The Merchant of Venice. London: York Press, 1998. and takes the money of her miserly father. A prose tale written in 1580 by Anthony Munday called Zelauto tells of two lovers, a money-lender, a flesh-bond, and two disguised ladies as lawyers. A ballad of Gernutus and Alexandre Silvain's The Orator, translated from the French (probably. by Munday), are yet more possible sources of the story of The Merchant.

Shakespeare was also influenced by a lost play called The Jew (1578), reported by Stephen Gosson, and by Marlowe's play The Jew of Malta, performed in 1589. Marlowe's play is about a Jew whose daughter loves a Christian. Some critics say it mixes tragic farce and heartless comedy with cynical satire on the avarice of Christians, Turks, and Jews. Barabas is the smart comic villain of the play whose intelligence is superior to Christians and Turks.

The Merchant of Venice was probably first performed some time in 1596-97. However, the first performance on record was in 1605 by the King's Men at Court, on Shrove Sunday. In 1701, an adaptation of the play was done by George Granville, named The Jew of Venice. As critic Nicholas Rowe wrote about the play in 1709: "THO' we have seen that Play Receiv'd and Acted as a Comedy, and the Part of the Jew perform'd by an Excellent Comedian, yet I cannot but think it was design'd Tragically by the Author."20

In 1741 , a restored version of the play was performed with Shylock as comic villain. The actor, Charles Macklin, was a distinguished

${ }^{20}$ ROWE, N. In: WILDERS (Ed.). Shakespeare: The Merchant of Venice, p. 25. 
comedian, but his Shylock was not received as comic, since he stressed the Jew's contrasted passions. "( $\mathrm{T})$ here is no doubt but MR MACKLIN looks the part as much better than any other person as he plays it; in the level scenes his voice is most happily suited to the sententious gloominess of expression the author intended; which, with a sullen solemnity of deportment, marks the character strongly; in his malevolence, there is a forcible and terrifying ferocity; in the third act scene, where alternate passion reign, he breaks the tones of utterance, and varies his countenance admirably." 21

Later, in the beginning of nineteenth century, a more humane Shylock appeared. In his criticism at the time, William Hazlitt writes that: "Shylock becomes a halffavourite with the philosophical part of the audience, who are disposed to think that the Jewish revenge is at least as good as Christian injuries." 22 In 1879 a performance with Henry Irving as Shylock and Ellen Terry as Portia ran for 250 nights. At that time The Merchant was seen as a romantic drama. Shylock was played as a persecuted Jew and Portia as a woman full of warmth.

A comic Shylock, a decadent bourgeois merchant in a red wig with only incidental Jewishness, appeared in the first decades of the twentieth century. Some critics point out that with the rise of National Socialism, Shylock was played in a more humanized way - except in Germany, of course. Performances of The Merchant with a less

${ }^{21}$ GENTLEMAN, Francis. In: WILDERS (Ed.). Shakespeare: The Merchant of Venice, p.26.

22 HAZLITT, Willian. In: WILDERS (Ed.). Shakespeare: The Merchant of Venice, p.27. comic Shylock, less evil Jew than mere usurer, became more common at that time. In 1946, John Palmer wrote: "Shakespeare set out to write a comedy about a stage Jew involved in a grotesque story about a pound of flesh. But Shylock, to satisfy his author, must seem to act as a recognisably human being would behave in the given circumstances and Shakespeare has humanised him to such good purpose that this comic Jew has become, for many brilliant and sensitive critics, a moving, almost tragic figure." 23

As we can see, both the origin of the play and its stage history suggest various interpretations of its identity. To the question of The Merchant of Venice's genre, the most reasonable answer is that it is (n)either a comedy (n)or a tragedy. The "happy" ending of Portia and Bassanio, Nerissa and Gratiano, and Jessica and Lorenzo suggests that The Merchant follows the conventions of Elizabethan comedy: all ends well! Besides this, the urban setting, the middle-class characters, their prosaic style of speech, and the festive atmosphere of the end of the play seem to reinforce its comedic aspect.

If we focus on Shylock, he can be pictured as a comic Jew: stubborn, obsessed and possessed by a single thought. In this sense, he is a character who takes advantage of the comic logic of the plot, which soon appears to be the opportunity for bringing him to life - subverting, somehow, the logic of the plot itself. "The plot determines the kind of character which Shakespeare created; but the character, once created, determines everything

23 PALMER, John. Shylock. In: WILDERS (Ed.). Shakespeare: The Merchant of Venice, p.114. 
he says or does." 24 Shylock combines the necessities of the plot with his "illuminations," which exceed those necessities. As Palmer observes: "then comes the first intimation that Shakespeare, having undertaken to supply his audience with a comic Jew committed to a barbarous enterprise, not only intends to make his conduct psychologically credible but has already realized in imagination what it means to wear the star of David:"25

Shylock. Signior Antonio, many a time and oft In the Rialto you have rated me About my moneys and my usances.

Still have I borne it with a patient shrug, For suff' rance is the badge of all our tribe. You call me misbeliever, cutthroat dog, And spet upon my Jewish gabardine, And all for use of that which is mine own. Well then, it now appears you need my help. Go to, then. You come to me and you say, 'Shylock, we would have moneys' - you say so, You that did void your rheum upon my beard And foot me as you spurn a stranger cur Over your threshold! Moneys is your suit. What should I say to you? Should I not say, 'Hath a dog money? Is it possible A cur can lend three thousand ducats?' Or Shall I bend low, and in a bondman's key, With bated breath, and whisp' ring humbleness, Say this:

'Fair Sir, you spet on me on Wenesday last, You spurned me such a day, another time You called me dog; and for these courtesies I'll lend you thus much moneys'? (Act I, scene iii)

Some commentators on the play point out that Shylock's repetitive manner stresses his comic image, setting the comic rhythm of the play. He is, surely, a man who speaks, and through his speech he forwards the plot. But the plot is then confounded with tragicsounding speeches, like Shylock's farewell to Jessica before she flees with Lorenzo.

Shylock. I am bid forth to supper, Jessica. There are my keys. But wherefore should I go? I am not bid for love - they flatter me.

But yet I'll go in hate, to feed upon The prodigal Christian. Jessica my girl, Look to my house. I am right loath to go.

There is some ill a-brewing towards my rest, For I did dream of moneybags tonight. (Act II, scene v)

In fact, the tragedy is in the time to come: in Jessica's flight, the rebellion of Shylock's flesh and blood, of 'his girl.' Nevertheless, for Palmer, the house and not Jessica stands at the core of Shylock's being. The house is also seen as a living thing:

Shylock. To gaze on Christian fools'with varnished faces:

But stop my house ears, I mean my casamentes, ... (Act II, scene v)

The critic is of the opinion that in this scene Shakespeare has done no more than humanize the stage qualities of the comic Jew: "Every stroke aims at our sense of comedy." Palmer also sees the scene with Salerio and Tubal as deliberately comic instead of emotionally tragic. For him, Shakespeare rather wants to emphasize Shylock's abnormally possessive affection than his concerned Jewish fatherhood. What is taken to be the most touching, eloquent, and humanizing speech of the play is, according to Palmer, the climax of the comedy, since it shows Shylock growing more humorous "as he becomes more poignantly enslaved to his obsession." 26

\footnotetext{
24 Ibid., p. 114.

25 Ibid., p. 118.
}

26 Ibid., p. 124. 
From this perspective, Shylock is a mechanical man who talks obsessively and wants revenge: "There is something grotesque even in his pleading, if you tickle us, do we not laugh? Shakespeare was not here concerned - he never is concerned - with pleading a case in morality.... The comically distorted image of Shylock the Jew is in effect a more telling indictment of Christian oppression, though Shakespeare was not primarily concerned with the aspect of the matter, than the fictitiously sentimentalised presentment of the character created for modern playgoers by Edmund Kean and his successors." ${ }^{27}$ In fact, Palmer argues that thinking and performing Shylock as humanly impressive spoils the comedy and impairs the moral effect of play, which lies in the irony of the comic in presenting reality exposing human beings' blindness to their own inconsistencies.

If we turn our attention to Antonio, we do not find a comic character, yet he 'plays' with the Jew (in both sense of performing with and contending against):

Antonio: Content in faith. I'll seal to such a bond, And say there is much kindness in the Jew. (Act I, scene iii)

Antonio and his fellows respond to the comic logic of the plot insofar as they oppose themselves to the Jew, or rather to the Jewishness of the Jew. Jews and Christians, their idiosyncrasies, their differences in faith and principles, are established from the beginning of the play as two opposite and opposing worlds. On the side of Christians, there are the gay, spendthrift young gentlemen of the comedies (Bassanio, Gratiano, Lorenzo)

\footnotetext{
27 Ibid., p. 126.
}

and Antonio, the open-handed merchant. On the side of Jews, there is Shylock, the inhuman usurer. This opposition asseverates the villainy of Shylock, highlighting his malevolence and cruelty. Its apex is the moment when Jessica, his flesh and blood, flees, leaving his house, taking his money; his jewelry, and his Jewish pride. Antonio satisfies the logic of the comedy, stressing Shylock's comic villainy as well as making possible Bassanio, Gratiano, and Lorenzo's love story and the conversion of the Jew to Christianity. As has been shown, however, this simple, Manichaean picture is broken by Shylock and Launcelot, who disrupt the logic of the comic plot with unexpected insights. Antonio's melancholy throughout the play is also a break in the comic logic of the plot insofar as it "keeps up" something in the air. For me, it is another privileged moment in the play - full of drama and, perhaps, tragic.

I resist looking at The Merchant as a simple comedy. Taking Antonio and Shylock as the center of my discussion, we find at the end of the play two "close" characters. They remain solitary: Antonio still melancholic and Shylock defeated. Two (and too) strangers to the final tableau of loving scenes, two outsiders. Shylock does not belong to Venetian society at all; Antonio does not belong to the world of consummated love, of marriage. Indeed, these two lonely men and the circumstances of their loneliness lead us to (re)think The Merchant, not as a comedy, but neither exactly as a tragedy.

We could conclude that the identity of the play remains (or not) ambiguous because of the ambiguous (or not) identity of Shylock and Antonio (which I will discuss in the 
following section). Or maybe, considering that identity implies a reflective attitude, the comic in the play has to look to the tragic in order to recognize itself as comic. If so, then comic and tragic are dramatically committed to each other.

\section{THE (AMBIGUOUS) IDENTITY OF ANTONIO AND SHYLOCK}

Portia. I am informed throughly of the cause. Which is the merchant here? And which the Jew? (Act IV, scene i)

I have already discussed Antonio and Shylock, who can be seen conventionally as two antagonists, but dramatically as committed to each other. In the first case, Jew and Christian, egoist and generous, bloodsucking moneylender and intrepid merchant, rude and gentle, they divide preferences (among the audience), raise laughs, and disdain one another. These are men who could never be fellows (Kameraden, camaradas, camarades, comrades) because they share nothing. In the origin of these words there is Kamára, a place under which people who live their lives become involved, become kameraden, camaradas, camarades, comrades. Camaraderie or comradeship means to share the same place, the same food, the same drink, and the same faith. And Shylock is aware of its "sacred" meaning:

Shylock. Yes, to smiell pork, to eat of the habitation which your prophet the Nazarite conjured the devil into! I will buy with you, sell with you, talk with you, walk with you, and so following; but I will not eat with you, drink with you, nor pray with you. What news on the Rialto? Who is he comes here? (ActI, scene iii)
Shylock and Antonio do not eat, drink, and pray together because "en fait, tout oppose les deux hommes: l'un est calculateur, l'autre généreux et même prodigue, l'un thésaurise, l'autre dépense, Shylock bâtit sa fortune sur la raison et la possession, l'autre risque la sienne dans folles aventures." 28 Nevertheless, they buy and sell with each other; business is permissible. Business (and not friendship) requires formalities, which in turn imply rules: the rules of Venice. Antonio, for the sake of his love for Bassanio, has to do business with Shylock and a bond is made: three thousand ducats to be paid in three months; otherwise:

Shylock... if you repay me not on such day, In such a place, such sum or sums are Expressed in the condition, let the forfeit Be nominated for an equal pound Of your fair flesh, to be cut off and taken In what part of your body pleaseth me. (Act I, scene iii)

It is certainly a diabolical bond, as Antonio remarks:

Antonio. Mark you this, Bassanio, The devil can cite scripture for his purpose. An evil soul producing holy witness Is like a villain with a smiling cheek, A goodly apple rotten at the heart. O what a goodly outside falsehood hath! (Act I, scene iii)

Nevertheless, Antonio agrees to the bond, and so makes a pact with the 'devil' (just like Faust). Traditionally, in the realm of private law, a bond between two persons becomes the law for (and between) the parties, who take the risk of this anticipation of the

28 OST, François, Temps et contract. Critique du pacte faustien. Annales de Droit de Louvain, n. 59 (1999), 1-2: 21. 
future (the contract, the bond). For Shylock, law is the absolute condition for leading a decent life, while for Antonio it is the minimum condition; it is an inadequate guide for life because it is indifferent to persons. ${ }^{29}$ Thus, for Shylock the bond assumes an absolute authority, while for Antonio it is not absolute yet it has authority. These two opposite men are, then, tied not by friendship but by the bond, the law.

Comically and/or tragically, Antonio breaks the law, the bond, when he is unable to pay Shylock the money he borrowed at the stipulated time. Once he breaks the law that tied them, their different worldviews become even more radically opposed.

Antonio irresponsibly forged the instrument of his own punishment in accepting the fleshbond. Shylock sadistically and resentfully seeks the realization of the law. On the one hand, there is the law (a bond) which is unjust in its terms - and, because of this, could be reconsidered. On the other hand, there is the spirit (and the will) of revenge. To accept the revocability of the forfeit, of the pound of flesh, means to accept the tangible force of the bond/law and its mutability. But for Shylock, the force of the law relies on its immutability:

Shylock. ... The pound of flesh which I demand of him

Is dearly bought, is mine, and I will have it.

If you deny me, fie upon your law!

There is no force in the decrees of Venice.

I stand for judgment. Answer; shall I have it? (Act IV, scenẹ i)
Shylock. My deeds upon my head! I crave the law,

The penalty and forfeit of my bond.

Instead, the bond/law "loin d'évoluer au bénéfice de la collaboration des partenaires, il se fige dans l'exécution mécanique d'une vengeance prémdéditée." 30

Shylock. To bait fish withal. If it will feed nothing else, it will feed my revenge. He hath disgraced me, and hind'red me half a million, laughed at my looses, mocked at my gains, scorned my nation, thwarted my bargains, cooled my friends, heated mine enemies-sand what's his reason? I am a Jew.... And if you wrong us, shall we not revenge? ... (Act III, scene i)

Shylock is asked by the Duke and by Portia to show his mercy and remorse, and thus to forgive the merchant, to which he replies:

Shylock. On what compulsion must I [be merciful]? Tell me that. (Act IV, scene i)

That is the question Shakespeare's genius brings out: why should one be merciful and forgive?

The answer to this question reaches the limits of one's (our) humanity. In the play, it reaches the limit of Shylock's humanity. But his human condition somehow makes it impossible to respond to that demand: he does not eat, drink, or pray with Antonio. There is no friendship/camaraderie/humanity between them, but hatred, rancor, humiliation, and a bond/the law. To forgive is to challenge the irreversibility of law and the irreversibility of time by the fact that, in forgiving, what is done can be reversed; one is able to undo what is done.

${ }^{30} \mathrm{OST}$, Temps et contract. Critique du pacte faustien, p.22. 
To such a difficult and almost impossible task of forgiving in the realm of (their/our) mundane affairs, the only solution is (or has to be) equally impossible: to venture in a trial in which the judge is not a judge but a disguised woman, in which a civil lawsuit ends in a criminal conviction against the plaintiff and a Jew is converted into Christian.

As we can see, there is no possible solution to Shylock and Antonio's antagonism. With both their relationship and their business, the solution is its improbability. To forgive, then, is as impossible as the trial Shakespeare shows us. Voilà, Shakespeare's revelation! At this point, I must return to the second of my considerations about Antonio and Shylock's dramatic commitment.

At the beginning of this section, I said that Antonio and Shylock should be seen as dramatically committed to each other. From this point of view, they are seen as sharing the same fate: two outsiders, two strange men in a hostile society in which they end up being lonely (as they always were). In his joylessness, wifelessness, and essential solitariness, Antonio is almost the Christian mirror of Shylock: "Each has to make a gesture against being overwhelmed.... The Jew makes his offer of friendship, he tries to escape from isolation by means of the only common link between himself and his enemies, his wealth. Antonio makes his gesture of sacrifice in entering upon a bond, through the only thing, which really means anything to him, his love.... Each makes his gesture and each is defeated ...."31
Shakespeare wisely and ironically makes them close to each other because there is no proximity/friendship between them. Portia, who is also wise, raises the crucial question: "Which is the merchant here? And which the Jew?" She lives in Belmont, but she knows Venice, a place of curious and enigmatic personal identities, a place of masks. Identity is at stake! We are (re)turned to Antonio, to the beginning of the play and to the cause of all this drama: "In sooth I know not why I am so sad.... I have much ado to know myself."

This dramatic statement recurs through the play. Antonio and Shylock, the Christian and the Jew, are the characters on whom this paper has mostly focused. This does not mean that they are the most important characters in the play, but they do embody the ambiguous types I want to explore, the dramatic and onerous ambiguity that somehow ascribes excitement and fear, pleasure and pain, to those who experience it. That is, the indeterminacy and insecurity of who and what one (we) is (are), is (re)presented in the narrative of The Merchant of Venice. Sypher points out that: "Greek and Elizabethan playwrights alike indicate that drama thrives on uncertainties in ages when the foundations of belief have been unsettled, where there are competing readings of experience, when logic has reached a point of diminishing returns." ${ }^{32}$ Shakespeare's characters are full of complexities like those we encounter in living persons and that makes it difficult, for instance, to classify most people as either hero or villain.

Perhaps Shakespeare did not think of an ambiguous Shylock or an ambiguous Antonio

31 MIDGLEY, The Merchant of Venice: A Reconsideration, p.204.

32 SYPHER, The Ethic of the Time, p.3. 
as he wrote the play. But to be in a plot, to become entangled, is a living experience. If we look to Shakespeare's theatre as such (as a living experience), and especially to The Merchant of Venice, an ambiguous Shylock and Antonio are allowed by our imagination; otherwise this would not be a (comic or tragic) drama.

(THE AMBIGUITY OF) THE LETTER OF THE LAW THAT EQUALS LAW THAT EQUALS JUSTICE THAT EQUALS REVENGE

Quelle différence y a-t-il entre d'une part la force qui peut être juste, en tous cas jugée légitime, non seulement l'instrument au service du droit mais l'exercice et l'accomplissement même, l'essence du droit, et d'autre part la violence qu'on juge toujours injuste? (Derrida, Force of Law, p. 927)

The dramatic (and ambiguous) experience of being Antonio and Shylock leads the two characters to another, no less dramatic experience: being in/for/before the law. What places law at stake in The Merchant of Venice is the sentiment of revenge. Posner, quoting Holmes, says: "law grows out of revenge." 33 Indeed, some legal doctrines were based on revenge; the history of law cannot ignore this fact. The whole idea of retribution in criminal law, in the sense that the punishment has to be proportionate to the wrong the aggressor/ defendant has done - retaliation for a wrong has its origin in revenge. To some extent, law has replaced revenge when it takes the conflict

\footnotetext{
${ }^{33}$ POSNER, R. Law and Literature. Cambridge, Mass. and London: Harvard University Press, 1998, p.49.
}

from the private to the public sphere in order to render it rational and institutionalized. Indeed, when people are not able to handle their own conflicts they appeal to the "authoritative" 34 instance of law in order to find a "rational" 35 resolution. Revenge is somehow the antithesis of rational thinking insofar as it is emotional, destructive, and passionate. Law has (among other things) this pretentious task of rendering rational/ reasonable one's (our) conflicting concerns, emotions, and passions. If and how it does this are issues which run throughout this paper. Clearly, replacing revenge through institutionalized forms of retribution or composition does not mean that it will no longer occur. Law replaces it as a (institutionalized) system, but not as a feeling.

According to Posner: "[l]iterary depictions of revenge can tell us something about revenge and about issues of law and justice that revenge adjoins or subtends; the lawyer's and social scientist's analyses of revenge can tell us something about literature." 36 In The Merchant of Venice, the flesh-bond story is a story of revenge as well as forgiveness. Looking narrowly at its legal

\footnotetext{
${ }^{34}$ The discussion on the authority of law is as endless as the discussion on the authority of the Rule of law. In very general terms "we" citizens consent in such authority in order to escape from a condition of absolute mistrust in which "bellum omnium contra omnes."

35 To act rationally or reasonably does not necessarily mean that wrongs will not be done or that law/rights will be respected and enforced. For example, Nazi Germany, fascist Italy, and South American dictatorships all acted under the name of the Rule of Law, cases in which the Rule of Law camouflaged tyranny.
}

\footnotetext{
36 POSNER, Law and Literature, p.49.
} 
implications, there is a loan formalized through a bond - a legal instrument intended to regulate a commercial deal - with a clause pledging a pound of flesh as a security against a default. Shylock, the moneylender, and Antonio, the borrower, agree with the terms of the bond and so the deal is settled. As I have said elsewhere, Shylock and Antonio, Jew and Christian, do not eat with each other, do not share anything expect the sentiment of animosity, but still they negotiate with each other. Antonio is unable to pay Shylock at the stipulated time since his ships are lost at sea, and so the loan goes into default. Shylock, who hates Antonio and whose daughter flew with a Christian taking his jewels and his dignity, brings suit to enforce the bond, the law. Indeed, Shylock wants revenge and he brings suit to (en)force the bond, the law: a pound of flesh to be cut and taken from Antonio.

Shylock... If you prick us, do we not bleed? If you tickle us, do we not laugh? If you poison us, do we not die? And if you wrong us, shall we not revenge? If we are like you in the rest, we will resemble you in that. If a Jew wrong a Christian, what is his humility? Revenge! If a Christian wrong a Jew, what should his sufferance be by Christian example? Why revenge! The villainy you teach me I will execute, and it shall go hard but I will better the instruction. (Act III, scene i)

Shylock. I'll have my bond! Speak not against my bond!

I have sworn an oath that I will have my bond. Thou call'dst me dog before thou hadst a cause, But since I am a dog, beware my fangs.

The Duke shall grant me justice. ...(Act III, scene iii)

For Shylock, revenge and the enforcement of his bond mean (to do) justice. Suddenly, there is not revenge, a bond, and justice, but rather one and the same thing that can be (called) either revenge or bond (law) or justice. For Shylock, like for most people, (the idea of) the letter of the law implies (the idea of) law, which in its turn, implies (the idea of) justice. Posner remarks that: " $[t]$ he lack of realism in the play's treatment of law extends to the procedures as well as the substance of law." 37 That is, the improbability of legal technicalities in the play concerning Renaissance law is obvious, but this is not the point. Shakespeare was not concerned with legal technicalities but with drama, which is there in Shylock's faith in the letter of the law, in this strict legality justified by a legal formalism to accomplish an unjust end - the letter of the law that equals law that equals justice that equals revenge.

Shylock has a bond, which literally says that a pound of flesh is to be cut and taken from Antonio. He believes in the authority of the bond, the law, to the same extent that he believes in the authority of the Old Testament: "an eye for an eye." The same literality allows Portia to understand that if a drop of blood were spilled, Shylock would be attempting to take the life of a Venetian citizen and thus committing an even worse crime.

Portia shows that interpretation is at stake in law and, more specifically, in adjudication. In the trial she seems to act reasonably and

${ }^{37}$ Ibid., p.106-7. For instance, the fact that at that time in Venice, "a defaulting borrower had the right to recover his forfeited property by coming up with the money is due on the loan, even if it is overdue, within a reasonable time." A real court would also lead Shylock and Antonio to an agreement once it had obtained Antonio's offer to double Shylock's principal. The trial, with a disguised judge and without lawyers for the parties, is another improbable legal technicality. 
with equity, recognizing that strict rules of law, however necessary to a well-ordered society, must be applied with sensitivity so that the spirit of the law is not sacrificed unnecessarily to its letter. Shylock is aware of his status as an alien in Venetian society and hence he is attached to the letter of the law as protection against judicial discretion that could be exercised against him. "A punctilious legalism is the pariah's protection." 38 If, on the other hand, Shylock had appealed to the 'spirit' of the law instead of its literality, he would have had a better argument to enforce his bond. Therefore, Portia wisely argues that rules of commerce in Venice must be observed and, as such, any agreement made according to these rules must be enforced.

Portia. It must not be. There is no power in Venice

Can alter a decree established.

'Twill be recorded for a precedent,

And many an error by the same example

Will rush into the state. It cannot be. (Act IV, scene I)

"A Daniel come to judgment! Yes, a Daniel!/ O wise young judge, how do honor thee!," the Jew replies. She thus gains his confidence in her legal skills and, relying on the same argument, says that: "(t)his bond doth give thee here no jot of blood;/ The words expressly are 'a pound of flesh'...." As we can see, Portia moves from an argument appealing to Shylock's sensitivity, asking him to forgive Antonio, to an argument which was Shylock's own and which appeals to the letter of law - but with a difference: Portia has the force, the authority. Whatever

\footnotetext{
${ }^{38}$ Ibid., p. 110
}

equitable, good, and just intentions Portia has in preventing the enforcement of the absurd bond, she is a disguised judge and also an interested party in the case. And she acts as such, that is, without the impartiality a judge must have.

Portia thus transforms a trial based on a civil suit into a criminal conviction against Shylock, since he, after all, attempted to take the life of a Venetian citizen. She arranges for things to come out right through a series of none-too-honest stratagems.

On the one hand, Portia's verdict satisfies the comedy, assuring a conventional happy ending in Belmont. On the other hand, it satisfies the purpose of this paper, showing that law through its force aims at channeling different self-interests to a common ground of (possible) reconciliation supported by norms, rules, and standards, ${ }^{39}$ but that this possibility is, inevitably, dramatic.

To recount the story of The Merchant of Venice is to venture into a complex web of conflicts in which the characters weave their identities not just as subjects, but also as 'legal' subjects. Questioning, complicating, destabilizing, bringing out paradoxes and ambiguities, showing the "illuminations" of the plot through Antonio and Shylock - subjects, subjects of law, subjects of morality, juridical and moral persons - is to problematize law and justice. Or, rather, as Derrida points out, it is " $[u] n$ questionement sur les fondements $d u$ droit, de la morale et de la politique." 40

${ }^{39}$ ROSENFELD, M. New Legal Formalism. In: DECONSTRUCTION AND THE POSSIBLITY OF JUSTICE. Cardozo Law Review. (11) 5-6, july/aug. 1990 , p. 1266.

40 DERRIDA, Force of law. In: Ibid., p.931. 
A flesh-bond is the link between Antonio and Shylock. The paradox, then, is introduced at the beginning: this link is fated to its dissolution and (or because of) a bond whose enforcement is fatal. We paradoxically experience the same fatality when "we" subscribe to a contract in order to have a "better" life in political and civil society, which in turn are the outcome of our individual and egoistic will (however intended to provide us a "better" life). We are fated in the modern liberal-bourgeois state to a constitutive egoistic will, which is our own, to render us a "better" life in a "wellordered" society; a will that, according to Hobbes, is either desiderium or appetitus and, as such, ambiguous and antagonistic.

Hobbes, who exemplifies this understanding, asserts: "the mutual transferring of right, is that which men call CONTRACT."4l The contract assumes the form of a pact or covenant (or bond) in a sense that "one of the contractors, may deliver the thing contracted for on his part, and leave the other to perform his part at some determined time after, and in the mean time be trusted." 42 According to Hobbes, contracts are communicated through signs, which can be either express or tacit: "Express are words spoken with understanding of what they signify: and such words are either of the time present, or past; as, I give, I grant, I have given, I have granted, I will that this be yours: or of the future; as, I will give, I will grant: which words of the future are called

${ }^{41}$ HOBBES, T. Leviathan. On the matter, form and power of a commonwealth ecclesiasticall and civil. New York: Touchstone, 1997. p.106.

42 Ibid., p. 106.
PROMISE." 43 In this sense, signs of contract are words of the past, present, and future. It is not by chance that 'will' is the key word to signify Hobbes's or even Shylock and Antonio's contract. 'Will,' on the one hand, signifies a present act of the will (one's or our will) and, on the other hand, a promise of an act of the will to come. And Hobbes continues: "because all contract is mutual translation or change of right; and therefore he that promiseth only, because he hath already received the benefit for which he promiseth, is to be understood as if he intended the right should pass: for unless he had been content to have his words so understood, the other would not have performed his part first. And for that cause, in buying, and selling, and other acts of contract, a promise is equivalent to a covenant; and therefore obligatory." 44 In willing (the moment of the contract), one will do such and such (the moment of promises). Hobbes's depiction of the 'State of Nature' is of a society where one is not able to make promises. Therefore, in the 'State of Nature' no contracts or covenants or bonds would be valid. For Hobbes, a 'state' where one is able to make promises and to accomplish them is, first, the outcome of one's individual will (in the present), by means of which a contract is settled. This latter is then itself an act of deliberation, i.e., an act of will (in the future).

Yet, precisely here resides Shylock's and Antonio's (and our) drama: this will, which signifies the contract, can, according to Hobbes, be understood either as desire or

\footnotetext{
${ }^{43}$ Ibid., p. 106.

44 Ibid., p. 107.
} 
appetite. According to the first understanding, desire comes from the verb desidero which, in its turn, comes from the noun sidus (singular)/sidera (plural). Sidera means the figures made by groups of stars, i.e., constellations. Sidera thus lead to the heights. Desiderare means to abandon the heights or be abandoned by them. Desiderium is the decision of taking our destiny in our own hands and desire is the conscious will obtained from deliberation. However, Desiderium also means a loss, a privation, a lack. Thus, desire is, on the one hand, decision, deliberation, and, on the other hand, lack, privation, loss. Hobbes says: "that which men desire, they are also said to LOVE: and to HATE those things for which they have aversion. So that desire and love are the same thing; save that by desire, we always signify the absence of the object; by love, most commonly the presence of the same." 45 The will as desire cannot escape the ambiguity that constitutes and defines it as well as the fatality of losing or lacking. Still following Hobbes, the will can equally be expressed by appetitus: "In deliberation, the last appetite, or aversion, immediately adhering to the action, or to the omission thereof, is that we call WILL; the act, not the faculty, of willing." 46 Appetitus comes from appeto which comes from peto, that is, to go to, to attack, to go to seek, to pursue - followed or not by violence. It also has to do with soliciting, to demand (at law). Appeto, then, implies to attack, to pursue; to solicit. But Appetitus is also a natural desire to satisfy our hunger and thirst. On the one hand there is activity: attacking, pursuing and soliciting; on the other there is passivity: need, lack.

In fact, every situation of will, desire, or appetite is dramatic, anguished... This is true, following Hobbes, for the modern state, formally known as the Rule of Law, as it is for Shylock and Antonio. For Hobbes, justice comes from the accomplishment of the contract, and only a coercive power, through punishment, could compel men equally to perform their contracts. For Shylock as well, justice means claiming his bond and for this reason he appeals to the court of justice of Venice (to [en]force the law): "There is no force in the decrees of Venice!" This is a case (perhaps there is no other) of law and justice implying force, an authorized force which "se justifie ou qui est justifiée à s'appliquer, même si cette justification peut être jugée d'autre part injuste ou injustifiable." ${ }^{47}$ And if it is the case as it is for Hobbes and Shylock that justice is to accomplish the law through an authorized force then, justice (when it becomes law) has to imply such force. In adressing Portia, Jessica says,

Jessica. (...) If law, authority, and power deny not,

It will go hard with poor Antonio.

With an excessive and unauthorized force, we would be back to a situation of private vengeance. For Shylock, Justice is equal to Law that is equal to what is written, i.e., the bond/rule: justice as law, law as rule, rule as justice.

Nevertheless, this is not the case for Antonio. Derrida puts it nicely when he says

\footnotetext{
${ }^{45}$ Ibid., p.48.

${ }^{46}$ Ibid., p.54.
}

${ }^{47}$ DERRIDA, Force of law, p.925. 
that, "je veux tout de suite et encore insister pour réserver la possibilité d'une justice, voire d'une loi qui non seulement excède ou contredit le droit mais qui peut-être n'a pas de rapport avec le droit, ou entretient avec lui un rapport si étrange qu'elle peut aussi bien exiger du droit que l'exclure". Yet Portia's arguments to release Antonio from his penalty are not realistic in the sense of their legal technicalities, they show the gap that (may) exist between justice and law in a strictus sensu, that is, as rule/norm and how contradictory they can be.

Thus, for Antonio justice runs in the opposite way, that is, in not performing the bond - perhaps in the same way for those who refuse to perform the contract in the liberal-bourgeois state. It is the case of justice contradicting law, where the latter is conceived as what is written, the bond/rule.

Shylock and Antonio lead us to conclude with Derrida that justice is an experience of the impossible: "Une volonté, un désir, une exigence de justice dont la structure ne serait pas une expérience de l'aporie n'aurait aucune chance d'être ce qu'elle est, à savoir just appel de la justice. Chaque fois que les choses passent ou se passent bien, chaque fois qu'on applique tranquillement une bonne règle à un cas particulier, à un example correctment subsumé, selon un jugement déterminant, on peut être sûr que le droit y trouve peut être son compte mais certainement pas la justice." 48

Finally, Shylock and Antonio convince me of the complicity among philosophy, law, justice and literature. Due to the predominance of legal formalism, especially legal positivism, in the study of law, law schools have not been the place to raise, discuss, and experience the aporias that are constitutive of law as such, i.e., as aporias. A paradigm of positive science has informed legal theory so that the study of law has been bound by a narrow conception of law as a system of norms/rules. Thus, neither the aporias nor the theoretical approaches that bring them out have been taken into account. But perhaps I should rewrite the last sentences in the simple past tense, as there are some new 'critical' approaches of and in law committed to (re)think it in other terms than the ones of legal positivism. This is, for instance, the case of Critical Legal Studies (CLS) and their deconstructive attitude, which offer a promising alternative for rethinking legal theory. Derrida points out that "les développements des 'critical legal studies' ou des trauvaux, comme ceux de Stanley Fish, Barbara Herrstein-Smith, Drucilla Cornell, Sam Weber et d'autres, qui se situent à l'articulation entre la literature, la philosophie, le droit et les problèmes politico-institutionels, sont aujourd'hui, du point du vue d'une certaine déconstruction, parmi les plus féconds et les plus nécessaires." 49 After all, Critical Legal Studies do not remain enclosed in pure speculative, theoretical, academic discourses, but engaged in a project to intervene in and change the world. 
LAW AND LITERATURE:

THE IMPOSSIBLE IN ITS POSSIBILITY AND THE POSSIBLE AS ITS IMPOSSIBLITY

Impossibility is not the opposite of possible: impossibility releases the possible.

(R. Beardsworth, Derrida and the political)

I have been stressing the ambiguities and contradictions that are at the origin of law specially positive law - through the discussion on the Merchant of Venice and, finally, I came to Derrida's consideration of law as an aporia. In fact, this could instead be (at) the beginning of the paper: law is an aporia. But the movement of the paper (and mine as well), however motivated by the relation between law and literature, could not be otherwise but from a looking for ambiguities and contradictions in law (through literature) and in literature (through law) to, then, the aporias that constitute both: law and literature.

"What if the law, without being itself transfixed by literature, shared the same conditions of its possibility with the literary object?" ${ }^{50}$ If law and literature share the same conditions of possibility it means that the origin of law is also that of literature, which is, after all, a non-origin. A story as a kind of relation is "linked to the law that it relates, appearing, in so doing, before the law, which appears before it." 51 Accordingly, law should not bring up any story unless it is without history and origin. As Derrida asserts, this is the law of the laws - moral, judicial, political, natural etc. "What remains concealed and invisible in each law is thus presumably the

\footnotetext{
${ }^{50}$ DERRIDA, Acts of literature, p.191.

51 Ibid., p.191.
}

law itself, that which makes laws of theses laws, the being-law of these laws."52 Thus, law appears and interferes but detached from any origin, that is, "(i)t appears as something that does not appear as such in the course of a history. At all events it cannot be constituted by some history that might give rise to any story." $" 53$

As we can see, the origin of the law is not an event but it is not pure fiction either. It is neither history nor fantasy but the law; the law of the laws and this is the aporia of law. "The aporia of law occupies the middle ground between reality and fiction, opening up the distinction, but always already exceeding its terms. ${ }^{54}$ An aporia is, then, this non-chemin which we cannot experience, this impossible in its possibility and possible as its impossibility.

For the aporia is also the law of literature. According to Derrida, literature is a kind of discourse that identifies its source of writing to be 'within' the aporia. Literature asseverates the non-origin of the origin of the law that is reinscribed as both the content and the event of the text. The non-advent of the law is the advent of a text. Then, law and literature come together in this impossibility of the account of the origin of law. The possibility of Shylock forgiving relies on its impossibility otherwise it would not be the case of forgiveness. It is this possibility as impossibility which literature witnesses.

\footnotetext{
52 Ibid., p. 192.

53 Ibid., p. 194.

${ }^{54}$ Beardsworth, Richard. Derrida and the
} political. p.34-35. 
The very characteristic of law is to be universal, ${ }^{55}$ that is, accessible to everyone and at all times but, essentially, it is not. It is then impossible to accede directly to the law, which is never immediately at hand. In Derrida words, "the very universality of the law exceeds all finite boundaries and thus carries this risk". ${ }^{56}$ In fact, law as well as literature, imply this ambivalent relation between the general and the singular. To the universality of law there is the singularity engendered by its enforceability. To the universality of a literary text - of what it narrates - there is its singular status as one and the only one (author(ity), copyrights etc).

A story does not tell or describe anything but itself as text to which it is impossible to accede in its proper significance. "The text guards itself, maintains itself-like the law, speaking only of itself, that is to say, of its non-identity with itself. It neither arrives nor lets anyone arrive. It is the law, makes the law and leaves the reader before the law." 57

Therefore, as well as the law, a text is not immediately accessible. Accordingly, a clear and graspable sense remains as hidden in its origin. Fiction of narration as well as fiction as narration is the (non)origin of literature. The non-origin of the literary text (or the law)

${ }^{55}$ As Derrida points out, Kant's moral law and the respect it calls for is due only to the moral law itself "which never shows itself but it is the only cause of that respect". Derrida is also concerned with the "as if" of the categorical imperative which, according to him, "enables us to reconcile practical reason with historical teleology and with the possibility of unlimited progress". See DERRIDA, Acts of literature, p. 190.

$$
\begin{aligned}
& { }^{56} \text { Ibid., p. } 196 . \\
& { }^{57} \text { Ibid., p. } 211 .
\end{aligned}
$$

does not diminish the necessity of what it tells (its law). Therefore, in order to reach the law and stand before it, face to face with respect, or to introduce oneself to it and into it the story becomes the impossible story of the impossible. ${ }^{58}$

The access to the law (and literature) is always a mediated access as we cannot reach it but only have relation with the law's representatives who are at the same time its interrupters and its emissaries. "We must remain ignorant of who or what or where the law is, we must not know who it is or what it is, where and how it presents itself, whence it comes and whence it speaks. This is what must be before the must of the law."59 According to Derrida, to be before the law is to be a subject of the law in appearing before it but what can either mean to not have access to the law, to be outside the law (an outlaw). $\mathrm{He} / \mathrm{she}$ is neither under the law nor in the law. $\mathrm{He} / \mathrm{she}$ is both, a subject of the law and an outlaw. Accordingly, Shylock (and also Antonio) remain subjects of the law and outlaws.

This is the law of the law, the process of a law whose subject it is here and there. After all, we do not know what the law is, who it is and where it is. "It is a thing, a person, a discourse, a voice, a document, or simply nothing that incessantly defers access to itself, thus forbidding itself in order to become something or someone. ... This nullification gives birth to the law, before as before and before as behind." 60

\footnotetext{
${ }^{58}$ Ibid., p. 199-200.

59 Ibid., p. 204.

${ }^{60}$ Ibid., p. 208-9.
} 
Well, law and literature experiences an aporetic relation, the same relation that Derrida finds in justice. In fact this is the point. This whole discussion on law and literature arrives at a tempting and equally aporetic idea of justice to which legal theory should commit itself if it aspires, somehow, to intervene and change the world. An idea of justice that must guide our actions in the sense of one's responsibility in taking decisions (in enforcing the law in the case of judicial officials such as judges), an idea of justice as aporia: "Une aporie, c'est un nonchemin. La justice serait de ce point de vue l'expérience de ce dont nous ne pouvons faire l'expérience... je crois qu'il n'y a pas de justice sans cette expérience, tout impossible qu'elle est, de l'aporie. La justice est une experience de l'impossible. Une volonté, un desir, une exigence de justice dont la structure ne serait pas une expérience de l'aporie n'aurait aucune chance d'être ce qu'elle est, à savoir juste appel de la justice." "61

This is not a messianic statement. It rather is a commitment that legal theory - legal theorists, philosophers of law, judicial officials, professors of law, legal professionals, etc. - should have: to (co)llaborate to a better (more equal, radically democratic and fairer) world. And Deconstruction is a 'possible' attitude for legal theory to do so. As Sam Weber nicely puts it, "what seems characteristic of the transferential place and history in which deconstruction is engaged, is that the transfer between languages - be they so-called "natural" or national languages, or to be they the discourse of individual "disciplines" - becomes dependent upon the transfers going on within their borders. Such internal transference tends to uncover 'hidden articulations ... within assumedly monadic totalities', and thus to open the possibility, and process of turning themselves, as it were, inside-out." 62

\section{VENICE'S STREETS AND BELMONT'S NIGHTINGALES SERENADE}

Portia. It is almost morning,

And yet I am sure you are not satisfied

Of these events at full. Let us go in,

And charge us there upon inter' gatories

And we will answer all things faithfully. (Act $\mathrm{V}$, scene i)

To bring a paper to an end is to acknowledge, just like in a trial (in some Latin languages, such as Portuguese, the word for trial is "judgement"), that a whole exhausting process has preceded it. Many things have been said, others have been passed in silence and based on both of them, sounds and silence, a sentence is pronounced. The content of the sentence, the decision, is the outcome of who interpreted such sounds and silence. The Merchant of Venice and this paper ( $n$ )either ends in Venice nor in Belmont but in (and by) my interpretation. For this reason, trials (judgements) and papers can be so controversial. Looking from this point of view a scaring but exciting sensation of uncertainty arises. Then, we forge instruments to deal with controversies and uncertainties that they produce. Such instruments are not to get rid of them but simply to deal with them in a certain way. To interpret The

${ }^{61}$ DERRIDA, Force de loi, p.946.

62 WEBER, In the name of the law, p.1515-1516. 
Merchant of Venice with a deconstructive attitude is the instrument I chose.

Conflicts, ambiguities, paradoxes, aporias drove my reading of Shakespeare's verses and prose. I was very much concerned with them as they carry the idea of what the dramatic is. Some Shakespearean scholars say that The Merchant of Venice is a legal play; I reply (sort of agreeing), it is a play about conflicts, ambiguities, paradoxes, aporias. Indeed, I am just reaffirming the same thing. From this perspective, law is dramatic and any attempt to preclude conflicts, ambiguities, paradoxes, and aporias sacrifices law, justice, and democracy.

Most of the people blame law (and its science) for being conservative. If a nonconservative understanding is to succeed law must be rescued from its isolation and be engaged in an ethical and political project. Deconstruction is a seductive, critical and responsible attitude to such rescuing.

\section{BIBLIOGRAPHY}

ARISTOTLE, Complete works. Ed. Jonathan Barnes. Princeton, New Jersey: Princeton University Press, 1994.

BEARDSWORTH, R. Derrida and the political. London and New York: Routledge, 1996.

BERNSTEIN, R. The new constellations. Cambridge, Mass.: The MIT Press, 1995.

BLOOM, A., JAFFA, H. Shakespeare's politics. Chicago: Chicago University Press, 1998.

BLOOM, H. The Western canon. New York: Harcourt Brace \& Company, 1994.

BROOK, P. Evoking Shakespeare. London: Nick Hern Books, 1998.

BROWN, J. R. (Ed.). The merchant of Venice. Cambridge, Mass.: Harvard University Press, 1959.
CARRIO, G. R. Sobre los límites del lenguage normativo. Buenos Aires: Ed. Astrea, 1973.

CORNELL, D. From the lighthouse: the promise of redemption and the possibility of legal interpretation. Deconstruction and the possibility of justice. Cardozo Law Review. (11) 5-6, july/ aug. 1990.

DERRIDA, J. Spectres de Marx. Paris: Galilée, 1993.

DERRIDA, J. Acts of literature. New York and London: Routyledge, 1992.

DERRIDA, J. Force de loi: le "fondement mystique de l'autorite". Deconstruction and the possibility of justice. Cardozo Law Review. (11) 5-6, july/aug. 1990.

DWORKIN, R. Law's empire. London: Fontana Press, 1986.

FISH, S. Doing what comes naturally: Change, Rethoric, and the Practice of Theory in Literary and Legal Studies. Durham and London: Duke University Press, 1995.

FISH, S. There's no such thing as free speech. New York and Oxford: Oxford University Press, 1994.

HABERMAS, J. Between facts and norms. Contributions to a discourse theory of law and democracy. Trans. by William Rehg. Cambridge, Mass.,: The MIT Press, 1996.

HARRIS, J. W. Legal philosophies. London: Butterworths, 1997.

HART, H. L. A. Derecho y moral.

Contribuciones a su análisis. Trad. de Genaro Carrió. Buenos Aires: Ed. Depalma, 1962.

HART, H. L. A. The concept of law. Oxford: Clarendon Press, 1975.

HELLER, A. A theory of modernity. Malden, Mass. and Oxford, UK : Blackwell, 1999.

HOBBES, T. Leviathan. Or the matter, form and power of a commonwealth ecclesiasticall and civil. New York: Touchstone, 1997.

KELSEN, H. Reine Rechtslehre. Wien: Verlag Franz Deuticke, 1960. 
LENOBLE, J. "La théorie de la cohérence narrative en droit". Archives de Philosophie du Droit, tome 33, la philosophie du Droit aujourd'hui, (1988): 122-139.

MENKE, C. The sovereignty of art. Aesthetic negativity in Adorno and Derrida. Trans. Neil Solomon. Cambridge, Mass. and London, England: MIT Press, 1998.

MOUFFE, C. (Ed.). Pragmatism and deconstruction. New York and London: Routledge, 1996.

NIKULIN, D. Mikhail Bakhtin: A Theory of Dialogue. Constellations, 5, (1998): 381-402.

NIETZSCHE, On the genealogy of morals and Ecce Homo. Trans. Walter Kaufmann and RJ Holingdale, New York: Vintage, 1989.

NOVAES, A. O desejo. São Paulo: Companhia das letras, 1990.

NUSSBAUM, M. Love's knowledge. New York and Oxford: Oxford University Press, 1990.

NUSSBAUM, M. Poetic Justice. The literary imagination and public life. Boston: Beacon Press, 1997.

OST, F. Temps et contract. Critique du pacte faustien. Annales de Droit de Louvain, v.59, 1999, n.1-2. Bruylant, Bruxeles

POSNER, R. Law and literature. Cambridge, Mass. and London: Harvard University Press, 1998.

POSTEMA, G. J. "Protestant" interpretation and social practices". Law and philosophy, 6, (1987): 291-2.
RAWLS, J. A theory of justice. Oxford: Oxford University Press, 1980.

RICOEUR, P. Oneself as another. Chicago and London: Chicago University Press, 1994. 363p.

ROSENDFELD, M. and ARATO, A.

Habermas on law and democracy: critical exchanges. Berkeley, Los Angeles, Londres: University of California Press, 1998.

ROSENFELD, M. Deconstruction and legal interpretation: conflict,indeterminacy and the temptations of the new legal formalism.

Deconstruction and the possibility of justice. Cardozo Law Review. (11) 5-6, july/aug. 1990.

SHAKESPEARE, W. The merchant of Venice. New York: Signet Classic, 1987.

SHAKESPEARE, W. Hamlet. In Four Great Tragedies. New York: Signet Classic, 1987.

SYPHER, W. The ethic of time. New York: A Continuum Book, 1976.

TAYLOR, C. Human angency and language. New York: Cambridge University Press, 1996.

WEBER, S. In the name of the law.

Deconstruction and the possibility of justice. Cardozo Law Review. (11) 5-6, july/aug. 1990. p.1515-1516.

WILDERS, J. (Ed.). Shakespeare: The merchant of Venice. London: Macmillan, 1997.

YORK NOTES ADVANCED. The merchant of Venice. London and Essex: York Press and Longman, 1998. 